\title{
THE CITY-IDEA IN ARGENTINA: A STUDY IN EVANESCENCE $(*)$.
}

\author{
RICHARD M. MORSE \\ Yale University
}

Within the current flood of scholarship on cities flows a modest stream of studies in quest of subjacent, comprehensive meanings: the city as idea, as image, as metaphor. In approaching the present this pursuit of the city-idea requires increasing ingenuity, for nowadays the "city" is fast disappearing. Politically, economically, and culturally it merges with region and nation; socially and ecologically it merges with the countryside. Just as "urban" race relations or "city" government are artificial subjects for social scientists who ignore national societies, so the cultural historian risks being scholastic or anecdotal when he insists on a literal inventory of urban images and attitudes. The city is no longer a sanctum, fort, imperial outpost, or walled mart. About all one can call it is a node of transactions within an unclearly differentiated field. The secular, industrial world strips the urban image of the rich meanings attached to the ancient Chinese "pivot of the four quarters", the Incas' umbilical Cuzco, the Aristotelian polis, or the Christian City of God. Often a part of the city - the slum, ghetto, or bidonville, Park Avenue or Wall Street - connotes more than the whole because the part less equivocally designates larger process. If, then, the "idea of the city" has shattered, contemporary cities provide rich vernacular and imagery for statements about the human condition. In approaching the present, pursuit of the city-as-idea or city-as-object shifts to exploration of city-as-language and citymas-setting.

The literature of Argentina is peculiarly suited for tracing the decomposition of the city-idea because an overriding dichotomy between Buenos Aires and the "interior" has dominated Argentine history for two centuries. This dichotomy refers not simply to a discre-

(*). - Revised version of a paper presented at the conference on "The City in History: Idea and Reality," University of Michigan, March 14-17, 1973. 
pancy in social structure, level of welfare, and way of life but to a powerful dialectic that has kelped mold national development. For generations it provided an organizing principle for a vision of politics, of society, of civilization, of historical process. Then, inevitably, the dialectic view proved inadequate, and the dichotomous metaphor splintered into fragments.

This paper reviews a series of moments in Argentine writing from national independence to the present. The moments selected do not so much illustrate attitudes toward cities per se as trace a sequence of outlooks on human destiny that chance to be enmeshed in urban preoccupations. The sequence appears to be developmental (although the premise of "development" must, in the last analysis, be questioned), and my treatment avoids the lowest-common-denominator principle. That is, I find it unsatisfying when Morton and Lucia White reduce sensitive critiques of the American city to a romantic attack on its overcivilization followed by an antiromantic attack on its undercivilization, or when Schorske groups European attitudes under three neat headings (the city" as virtue in the eighteenth century, the city as vice in the early nineteenth, the city as beyond good and evil in the late nineteenth) (1). Their technique seems more nearly the TV cameraman's than the historian's. Different "editing", one suspects, might have permitted a switching of labels.

The forbidding nomenclature of social science yields our first approach. In an influential article Redfield and Singer proposed that large citics may be classified as predominantly orthogenetic or heterogenetic (2). The former are administrative and cultural cities "of the moral order" which transform a Little Tradition into a Great one by projecting an old culture into "systematic and reflective dimensions" (Peiping, Lhasa, Uaxactun). The latter are commercial, entrepreneurial, and managerial cities "of the technical order" which create fresh modes of thought that challenge or reach beyond established cultures (Marseilles, Lübeck, London, New York, Shanghai, Bombay). The orthogenetic city reworks indigenous traditions into coherent synthesis. The heterogenetic city is a meeting ground for conflicting traditions, a locus of heresy, dissent, and intellectual deracination.

Redfield and Singer allude also to a hybrid "colonial" city which carries a Great Tradition to outlying areas but compromises it to meet

(1). - Morton and Lucia White, The Intellectual versus the City (Cambridge, 1962); Carl E. Schorske, "The Idea of the City in European Thought: Voltaire to Spengler" in: Oscar Handlin and John Burchard, eds., The Historian and the City (Cambridge, 1963), pp. 95-114.

(2). - Robert Redfield and Milton B. Singer, "The Cultural Role of Cities," Economic Development and Cultural Change 3, 1 (1954): 53-73. 
local circumstances. Once an "outpost" zone becomes independent, is it possible, they ask, for a new capital to reverse its function and assist the formation of an "indigenous" culture? García-Bouza feels that the terminology fails to account properly for Latin American cities, for which he proposes a third term, "allogenetic" (3).. An allogenetic city transplants an alien culture to a new territory in behaif, at least initially, of the original centers of that culture. Such a city comes to mediate between its hinteriand and a variety of foreign centers. But even when it assumes heterogenetic functions, and even after the formal colonial bond is snapped, the city's early orientation toward distant centers of cultural and political influence will long endure, narrowing the range of "acceptable" features that it assimilates (4).

If the term "allogenetic" yields a handle for Argentine cities, above all Buenos Aires, it is appropriate that our literary journey commences with the impressions of a visitor from an imperial power, Captain Francis B. Head (1793-1875), whose Rough Notes Taken during some Rapid Journeys across the Pampas and among the Andes were published in 1826, shortly after Argentine independence (5). Sent from England to investigate the collapse of some Andean mining companies, Head twice made the round trip from Buenos Aires to the Cordillera, logging more than six thousand miles. Though from time to time he admired the grandeur of the setting or the pride and prowess of the gauchos and Indians, ultimately he viewed the whole theater as one where the human species had become indolent and degraded. For this observer who harbored no self-doubts, who made easy associations between entrepreneurial energy' and moral integrity, the Plata provinces were the antipodes.

Although Buenos Aires had quintupled its population in eighty years and was overtaking Lima, historic City of Kings, in size and commercial importance, Sir Francis found it a squalid provincial town with pitiful pretensions to elegance, the creature of a primitive rural domain. Drinking water was impure, streets were badly paved, houses were comfortless and moldy, furnishings were tastelessly chosen and displayed. In provisioning the town the gauchos showed "want of attention to those arrangements which are generally met with in civilised communities". Sides of beef were dragged along the street, torn at by

(3). - Jo:ge García-Bouza, Factors of Change in Latin America, the Case of the Allogenetic Urban Setting (Buenos Aires, 1966), pp. 27-33.

(4). - Argentina is adduced as a "purer" case of allogenetic urban concentration than Mexico or Peru with their elaborate Amerindian civilizations.

(5). - Sir Francis Head, prolific essayist and biographer, had fought at Waterloo and was later Lieutenant-Governor of Canada. For his life see Sydney Jackman, Galloping Head (London, 1958). 
dogs; necessaries, excepting meat, were dearer than in London. In this setting Head's immigrant compatriots fell prey to bodily torpor and "habits of carelessness and dissipation", lapsing from the state of grace that English society effortlessly sustained. A group of Cornish miners were agreed that "They had sooner work their fingers to the stumps in England than be gentlemen at Buenos Aires".

Little in Head's account suggests that Buenos Aires was virtually the size of Boston, that it had been a viceregal capital, that it boasted a university and scientific societies, and that it had a hundred wholesale houses while Córdoba, largest city of the interior, had none. Although he referred in passing to the "power and influence" of Buenos Aires, whose interests were "often at variance with those of the inland provinces", his best guess was that the latter would soon assert their autonomy. Buenos Aires province was one of several competing jurisdictions and its capital a mere extension of the primitive interior. Plainsmen and city dwellers, for example, seemed a single breed in their resistance to the humid climate: "The Gauchos and even travellers sleep on the ground, and the inhabitants of Buenos Aires live in their damp houses without complaining of rheumatism, or being at all subject to cold". The Platine provinces were barely on the threshold of "progress towards civilisation" and awaited the immigration that would rouse the present populace from indolence. Meanwhile the ocean was the boundary between civilization and primitivism, and the periphery on which Buenos Aires lay had its center not in Europe but at the heart of the pampas.

Twenty years after Sir Francis' strenuous travels, Domingo Faustino Sarmiento (1811-1888) published his classic Civilization and Barbarism, the Life of Juan Facundo Quiroga (1845). A sentence from Head on the "prodigious" extent of the pampas provided an epigraph, and the implicit theme of his Notes was elevated to Sarmiento's title page. Now, however, the civilization-barbarism dichotomy was no longer transatlantic but was rendered as a conflict internal to Argentine society. The opening chapters present Argentine cities as prospective bastions of civilization which are to radiate order and prosperity to the countryside.

All civilization, whether native, Spanish, or European, centres in the cities, where are to be found the manufactories, the shops, the schools and colleges, and other characteristics of civilized nations. Elegance of style, articles of luxury, dress-coats, and frockcoats, with other European garments, occupy their appropriate place in these towns. 
City and country were "two distinct forms of society". On the pampas, in fact, society had wholly disappeared, leaving the isolated, selfconcentrated feudal family. Sarmiento doubted whether so "monstrous" a form of association existed anywhere else in the world. For him, "society" implied a set of outlooks, patterned behavior, and organizational formalities rather than an inner logic of institutions. The stress of his sociology was attitudinal, not morphological. Thus cities represented disciplined intellect while the plains were raw energy, unshaped by incentives and therefore productive of lethargy .

The most conspicuous "foci of civilization" were Córdoba and Buenos Aires, the former disseminating a retrograde version based on the Spanish legacy of the Councils, the Commentators, and the Digest, the latter a progressive Anglo-French version informed by Bentham, Montesquieu, and French literature in general. Although Sarmiento considered both versions legitimate, he observed that the Spanish one degenerated more swiftly in contact with the telluric forces of America. To confirm this one needed only compare the neat yards of German and Scottish colonists with the unkempt settlements of "natives".

Buenos Aires, exposed to modern Europe and strategically located for commerce, was destined to become "the most gigantic city of either America", a New World Babylon. Fulfillment of the promise had been delayed under Spanish rule by a "senseless colonial policy" that deafened the city to provincial cries for a share of its civilization, industry, and European population and subsequently, after independence, when the provinces revengefully imposed the tyrant Rosas on Buenos Aires, archetype of the barbaric provincial caudillo. Argentine independence was thus twofold: first, a "civilized" war of the cities against Spain; second, the rural caudillos' war against the cities to secure political emancipation and satisfy their "hatred of civilization".

In his subsequent Argirópolis (1850) Sarmiento's moral fervor abated as he took up the economic geography of the urban question. $\mathrm{He}$ found that the sole egress for Argentina's fertile" heartland was via the overland routes that converged on Buenos Aires. Thus the prosperity of inland towns was in inverse relation to the cost of transporting their produce to Buenos Aires, where European markets determined export prices. Sarmiento proposed breaking this straitjacket in two ways: first, by multiplying the routes of access to the river system of northeast Argentina; second, by creating a new city, Argirópolis, on an island in the Plata estuary as a capital for the Argentine Confederation and other riverine states that had splintered from the Plata viceroyalty (6). Such a city, he claimed, would be a strategic defense point for Plata). 
the expanded Confederation and a central emporium that would stimulate, not preempt, the trade of an archipelago of urban centers.

Sarmiento's prescription was in part inspired by a trip to the United States whose capital, he noted, had been sited to equilibrate rivalries among cities without dampening their commercial impetus. What he failed to consider was that here sectional interests had already become articulated and orchestrated within the framework of the Union. Washington was designed as a theater of government, not an engine of political unification or commercial development. But enthusiasm for his convictions blinded Sarmiento to the hazards of analogy, as it had in Facundo when he likened the gauchos to Bedouins. Indeed, both Facundo and Argirópolis reflect the author's immense impatience with the skein of historical causation, and both present an abstracted image of "the city" - in one case a source of moral energy, in the other a. source of commercial drive and political organization. To realize the ideal, whether by purging existing cities of tyranny and tumult or by creating a new City of Silver, would have required, Sarmiento intimates, more of sheer will and vision than of political acumen and historical sensitivity.

Sarmiento's seeming naivety and his pontifical fervor provoked another giant to three decades of polemical attacks which by no means subsided during Sarmiento's presidency of the Republic (1868-1874). For Juan Bautista Alberdi (1810-1884) Sarmiento's vision of society was like a daguerreotype, faithful in detail but a copy in reverse (7). How, he asked, could Sarmiento call the countryside "barbaric" when rural production yielded the nation's wealth? And how could he call the city "civilized" when Spanish policy had been designed to inhibit urban manufactures and the cultivation of arts, letters, and science? The barbaric gaucho, wrote Alberdi, "represents European civilization better than Sarmiento, an unproductive, sterile worker on a lifetime sinecure, who lives like a domestic servant off the wages of the State, his patron". Ostensibly, Sarmiento's book excoriates his two archenemies, the provincial tyrant Quiroga and the national tyrant Rosas. But

(7). - For this historic duel of pens see "Las vidas paralelas: Alberdi y Sarmiento" in Bernardo Canal Feijóo, Constitución y revolución (Buenos Aires, 1955), pp. 365-421, and Carlos Mouchet, "Alberdi y Sarmiento, planificado:es y precursores de programas de desarrollo económico," Revista de Administración Pública 2, 7 (1962): 11-29. Alberdi's case is set forth in "Cartas sobre la prensa y política militante de la República Argentina" (known as the "Cartas Quillotanas," 1853), "Palabras de un ausente en que explica a sus amigos del Plata los motivos de su alejamiento" (1874), and the posthumous "Facundo y su biógrafo." The first two items are in the Obras completas (8 vols., Buenos Aires, 1886-87), IV: 5-94 and VII: 136-75; the third appears in a modern edition as La barbarie histórica de Sarmiento (Buenos Aires, 1964). 
in fact, Alberdi charged, Sarmiento harbored secret sympathies for the strong man and had composed a Machiavellian handbook for the complete caudillo.

What exasperated Alberdi was Sarmiento's immersion in his subject, his incapacity to stand aloof and delineate the logic of institutions. He had fallen into the idealist fallacy of taking the frock coat for civilization and the specific tyrant for a system of tyranny. Alberdi found it puerile to account for Rosas as a gaucho malo who seized power to pervert Argentine institutions. Rather, prior concentration of public power and commercial control in Buenos Aires had kindled and corrupted his political ambition. Rosas the man was an accident; the tyranny he personified was a permanent condition. After the defeat of Rosas Alberdi felt that Buenos Aires' monopoly of wealth, power, and services perpetuated caudillism under a changing guise. The caudillo of the plains yielded to the caudillo letrado of the cities, and Sarmiento acceded to the presidency as "Facundo II". The new caudillo used the sophism as his knife.

He's not the caudillo in gaucho leggings but the caudillo in a frock coat; he's still a barbarian, but a civilized one. His motto is civilization and barbarism, that is, both things united forming a single whole: a barbaric civilization, a civilized barbarism.

For Alberdi, then, civilization and barbarism did not signify dichotomy between city and country but coexistence of railroads and civil strife, soaring customs receipts and a national debt, public schooling and persecution of intellectuals, electoral freedom and official candidacies.

The rift between Sarmiento and Alberdi was not so much one of policy and ideals as one of intellectual stance. Alberdi tried to view institutions at a remove, to trace designs inherent in the object of scrutiny. Sarmiento - known as "Don Yo", or "Mr. First-Person-Singular" - projected himself vehemently into his subject matter. The coherence he gave it was personally experienced, not a cause-and-effect sequence discerned in the external world. As a young man he had know an aging landowner and inveterate gambler who, for want of a priest in the "barbaric" countryside, led his household in prayer every Sunday evening. Sarmiento sobbed at the reverence of that "pure-minded man", felt his nerves vibrate, imagined himself transported to the age of Abraham. Sarmiento's life role was that of a fatherly schoolmaster who addressed minds and hearts, not national institutions. When in later years he essayed a "sociological" study, Conflict and Harmony of the Races in America (1883), he failed to digest his patchwork of authorities; the book had no center, no clear message. 
Both men died in the 1880 s, disillusioned and politically rejected, at the threshold of a half century of national development which has few parallels in modern history. Much of what each had envisioned now came to pass: the taming of the pampas, a transportation revolution, soaring productivity, political unification, mass immigration, universal education. Transatlantic "civilization" was about to transform both city and country in this tumultuous American hinterland. Precisely at this juncture doubts arose regarding the wholesomeness of such civilization and of its hybrid forms on Argentine soil. These apprehensions pervade La gran aldea by Lucio Vicente López (1848-1894), published in 1884, the year of Alberdi's death (8). The title, "The Great Village", refers to a Buenos Aires of 400,00 inhabitants growing at five per cent a year whose big-city ways had left its provincial soul intact. The subtitle, Costumbres bonaerenses - inspired by Daudet's Moeurs parisiennes - identifies it as a slight, evocative composition with none of Sarmiento's oratnrical thunder or Alberdi's intellectual lightning. Yet even in its mannered style and from its urbanite, bourgeois perspective, the book made a point solid as mahogany, namely, that Argentina might have a usable past. Now that the strenuous chapter of nation-building had closed, one could pause to recollect a bygone quality of life. Vignettes juxtaposing the city of 1880 with that of 1860 evoke a genius loci of yesteryear lacking artificiality and commercialism.

Those were the times of commercial good faith, and not today, when the huge display case seduces the eyes without satisfying the need to touch which our mothers claim by indisputable right. ... What shop clerks they were! How far today's French and Spanish shopkeepers are from having the lineage and social graces of that gilded youth, bo $n$ of the land, last scions of the aristocratic retail trade of the colony. No lady or girl ever walked down the street without offering warmest greetings to the little sidewalk social circle seated comfortably on chairs and presided over by the proprieto:

By 1880 the city's bourgeoisie had adopted the cult of tapestries and bibelotage. The prime agents were two: the Jewish importer and second-hand dealer, or brocanteur, and the fatuous customer who passed as a connoisseur. The high priest of the cult was a Dr. Montifiori, whose mansion:

(8). - A modern edition with an informative prologue by Teresita Frugoni de Fritzsche was published at Buenos Aires in 1965. The innumerable gallicisms of the text are translated in footnotes for today's less cosmopolitan
readers. 
... paid its tribute to fashion. A pureblood aristocrat would have found much incongruence the:e-much that was apocryphal or frivolous-but the fact was that Montifiori also knew about Japanese ware, Gobelins, Flemish tapestry, Venetian glass, old porcelain and bronze, lacquers and cloth f om Persia and Smyrna.

All the centuries, all ages, all cu.toms paraded there, in doubtful synchronism perhaps, but with a dazzling brilliance which at first glance caused the most $\mathrm{k}$ cowledgeable person to blink and declare his conviction that Dr. Montifiori was wholly a man of the world.

If urban "civilization" could be seen as meretricious and as perverting a simpler, self-coherent way of life, so the long-despised countryside might be revealed as the last domain of sociability. The journalism and poetry of José Hernández (1834-1886) reversed Sarmiento's dichotomy, at least in its literal terms, and served a manifesto against the salon culture and ignoble politics of the "great village". In newspaper articles Hernández charged that cities, especially Buenos Aires, were the source of Argentina's political chicanery, factionalism, despotism, and financial mismanagement. Internally the cities protected the freedom and prosperity of their compact populations by "a tacit pact of mutual defense"; but the penurious rural domain lay abandoned, the arbitrary will of the caudillo its only law (9).

Hernández' masterpiece, Martín Fierro, is a long narrative poem published in two parts, "The Gaucho Martín Fierro" (1872) and "The Return of Martín Fierro" (1879). As a soldier Hernández had experienced frontier life, and his political involvements placed him at grips with his nation's dilemmas. For urban readers, it has been said, he had a political message, for rural ones a pedagogical mission. Although Hernández criticized Facundo and Sarmiento's policies (in fact took refuge in Uruguay during Sarmiento's presidency), Martín Fierro was conceived on a different plane from its author's pamphleteering. Here, "city" and "country" are never rendered in the sharp detail that Sarmiento and Captain Head used to such effect. The poet seems to interiorize experience, retreating from externals of time, place, and circumstance. Many characters are anonymous, while the names of Fierro and his friend Cruz recall the sword and cross of the Song of Roland. The three settings which frame the action are more akin to states of soul than to geographic localities. One of these is the pastoral world of the gaucho, perceived not as a political or

(9). - José Hernández, Prosas del autor de "Martín Fierro" (Buenos Aires, 1944), pp. 83-88. Also: Buenos Aires (province), Legislatura, Câmara de Deputados, Personalidad parlamentaria de José Hernández (3 vols., La Plata, 1947). 
economic domain but as a place where a man finds all that is needed for community: a ranch of his own, wife and children, friends and sociability. Here he possesses God's two finest gifts to man, "the word" and friendship. This "word" is not decorative or ceremonial, much less the sophism of Alberdi's caudillo letrado. Nor is it simply the coin of camaraderie. It is the capacity that, in Ernst Cassirer's sense, differentiates man from animal, or the "word" of Genesis that defines humanity. Although the gaucho may seem as brutish as an ostrich, the shadows of ignorance at least distinguish the light:

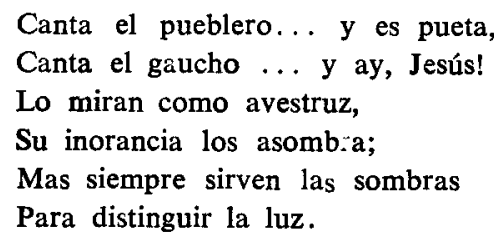

(The townsman sings and he's a poet. The gaucho sings and, oh my God! they look at him like an ostrich. His ignorance astounds them-but the shadows always serve to distinguish the light.)

The gaucho's, then, was a "natural" setting. He dwelt in his rancho like the fox in his cave, while his language elucidated rather than obfuscating his reference points in the world. What for Sarmiento was a "monstrous" society of isolated, inarticulate families becomes here a warm and "natural" human condition.

The poet evokes two other settings. One is a distant domain of the city or "Government" which yields vague emanations of power and hierarchy embodied in mysterious regulations, persecutions, and exemptions but never personalized in human emissaries. At the other extreme is a remote, Kafkaesque "frontier" created by city needs and imperatives. Banishment thither is a worse fate than deprivation, punishment, or violence, for in exile the gaucho is orphaned, expelled from home and family, condemned to silence and thus to solitude and loss of humanity. In the first part, the "Ida", Fierro had set out for the frontier bold and combative. In the "Vuelta" he has lost his spirit of rebellion. Though still unreconciled to "civilization", he is now resigned to the encroaching urban and governmental order. When the second part ends with Canto thirty-three, the age of Christ the poet reminds us, we feel that Hernández himself has suffered a change. Martínez Estrada suggests that in Part I Hernández was Martín Fierro, while in Part II Fierro becomes Hernández (10).

(10). - Ezequiel Martínez Estrada, Muerte y transfiguración de Martín Fierro (2 vols., Mexico City, 1948), I: 74. 
The earlier writers, Sarmiento and Alberdi, fused scientific issues of economics and politics with the sentimental one of mediating "civilization" to a society perceived as primitive and inchoate. Once mediation was achieved the lines of inquiry became disjoined. Scientific inquiry accepted the fait accompli, with its ambiguous results, and continued to scout possibilities for improving national institutions. The past century has yielded a harvest of frequently probing diagnoses of the urban phenomenon (11). Sentimental inquiry, to be examined in the balance of this essay, suspended utilitarian considerations and addressed the question of "authenticity", now that civilization, as Head, Sarmiento, and Alberdi had understood it, was no longer a sacred cow. The sentimental quest transcends the city-country dichotomy yet in subtle ways acknowledges it. It also leads us to certain outstanding imaginative writers of the present century rather than toward "urban" literature, or the "urban novel", as such.

Don Segundo Sombra (1926), the classic idyll of pampas life by Ricardo Güiraldes (1886-1927), may seem an unlikely source of illumination for the world of cities. Yet the opening sentence unobtrusively sketches an urban scene as a master image for the whole novel:

On the outskirts of the town, some ten blocks from the main square, the old bridge throws its arch across the river, linking the houses and gazdens to the placid countryside.

This town in which Fabio, the narrator, lived as a youth was stamped on the land with rigid geometrism, its forty blocks of flat, monotonous houses divided into meticulous, invariant squares. One of the houses belonged to the orphaned Fabio's aunts and was his "prison". Only the curve of the bridge relieved the town's cramped angularity, leading to a wider, freer realm.

One day the boy met the mysterious horseman Don Segundo Sombra and eventually set out across the arching bridge to join him. In an earlier age, Fabio reflects, what a caudillo he would have made! But Don Segundo's is a lone, anarchic spirit that wilts in intercourse with men. His action is the endless ride. He never seeks mastery of others, yet unlike Martín Fierro he is never at their mercy. The talk he loves is soliloquy, a sacramental utterance rather than the didactic speech of Fierro. The pampas that Fabio and the reader experience

(11). - For example: Alberdi's La República Argentina consolidada en 1880 con la Ciudad de Buenos Aires por capital (Buenos Aires, 1881); Juan Alvarez, Buenos Aires (Buenos Aires, 1918); and current research at the Center for Urban and Regional Studies of the Di Tella Institute in Buenos Aires. 
under Don Segundo's tutelage have unreal, mythical qualities (12) . As the boy rides with the gauchos he slips into a nirvana-like state; he dozes with open eyes and feels that he will ride forever, without thought, lulled in the cradle of the horse's stride.

At length word comes that Fabio's father has recognized him and bequeathed him property. Sadness, then humiliation and anger overwhelm him. Till now, being an orphan (guacho) and a gaucho had been one; "both meant child of God, child of the pampa, child of oneself" (13). Now legitimacy threatens to diminish his freedom. He longs to flee respectability as Martín Fierro fled a posse. Fabio's new roots and status produce the same effect that Martin Fierro's lack of them had, the sense of being an outcast. But the protest is temporary; he accepts his new condition.

It is conventional to observe that Sarmiento's gaucho was vigorously experienced, that Hernández' was wistfully perceived as passing into history, and that Güiraldes' was a phantom or mythic evocation. At a deeper level, however, Don Segundo is precisely the study of a "reality" toward which the triadic structure moves. In the small-town setting Fabio is orphaned, "without grace". Once he escapes to the pampas he finds grace and lives as a child of God. But life on the plains, without center, boundaries, or direction, is not wholly actualized; it is in this sense a bit eerie, as the hideous crab beds or Don Segundo's odd falsetto voice on occasion remind us. Only when Fabio inherits property with its specific responsibilities is he a vessel for the grace which has touched him. Don Segundo was thus the shadow, the "sombra", by which Martín Fierro had distinguished the light. The antinomies of property and freedom, roots and mobility, town and pampas are reconciled in the dialectic of redemption.

Like Martin Fierro, the writings of Guiiraldes obey inner promptings that float free of the author's social or political vaticinations. In this regard Eduardo Mallea (1903 -) is more akin to Sarmiento. The logic of his authorship is not internal to each work but derives from propositions and anxieties that inform all his writings. Because Buenos Aires is so frequently the scene of his fiction and the source of his preoccupations, Mallea can be related to the urban theme more

(12) . - Barufaldi contrasts Martín Fierro's hopeless search for anchorage with Don Segundo's directionless movement in a world of sheer horizon. Eugenio Castelli and Rogelio Barufaldi, Estructura mítica e interioridad en "Don Segundo Sombra" (Santa Fe, 1968), pp. 38-45.

(13). - The word guacho is of Quechua origin, and some claim that "gaucho" derives from it. That is, there may be etymological basis for the affinities, so important to Martín Fierro and Don Segundo, between orphanhood and the gaucho's condition. Martínez Estrada, Muerte y transfiguración, I: 24146 . 
explicitly than Hernández or Güiraldes. His intellectual autobiography, History of an Argentine Passion (1937), and his fiction are suffused with a sense of impending doom that jeopardizes individual freedom and the common morality. Yet the issues he finds germane to the modern crisis are precisely those to which Sarmiento had given prominence: the tension between Europe and America and Mallea's own "barbarism and civilization", rendered as "visible" and "invisible" Argentina.

Mallea describes the Americas in the vein of Buffon and Hegel, as being still in formation, their social life unshaped and disarticulated, their environment scarred by "horrendous, unredeemed novelty". European societies, in contrast, are coherent, rich-textured, and prolific in human types; they issue from seamless traditions and produce high cultural achievements; they reflect the harmony of man and environment. By the 1930s, however, Mallea sensed that Europe's delicate balance was taxing private lives more heavily and that the old regime was dissolving. Argentina was receiving miasmas from afar, "sanguinary malevolence from overseas". Clearly, Argentine cities might be thought to disseminate these vapors of intolerance and neo-primitivism just as they had once radiated "civilization".

Mallea's notion of a "visible" and a "submerged" Argentina reinforces the image of the city as philistine or subversive, but only to a point. Surface Argentina is an elaborate prevarication, a world where life is lived out as farce, bereft of sacramental value. Its culminating expression is Buenos Aires, primordial challenge to national "authenticity". The city dweller's blurred and corrupted speech attests his receptivity to external influence and his inability to transmute it into a culture of his own (14). When Mallea speaks thus of Buenos Aires, or when he intimates that the Argentine countryside may be more "authentic" than the townscapes, one suspects that his moral dichotomy may correspond to a rural-urban one which inverts Sarmiento's. But his distinction is not so simple. He also observes that rural villagers may be unwashed and indolent and the idolized gaucho may lack the nobility of the true Argentine patrician.

When Mallea defines "invisible" Argentina it becomes even clearer that the city plays no immutable role in his thinking. The "submerged" nation connotes organic relation between man and land, a potential for compelling cultural identity and for moral excellence. His most

(14). - In 1941 the Spanish man of letters Américo Castro sparked a savage debate over the authenticity of "the language of Buenos Aires." See Américo Castro, La peculiaridad lingüistica rioplatense (2nd ed.; Madrid, 1961); Jorge Luis Bo-ges and José E. Clemente, El lenguaje de Buenos Aires (new ed.; Buenos Aires, 1963). 
arresting expression of the ideal is through personification, as when he symbolizes Argentina by a woman (The Bay of Silence, 1940) or even likens its geography to a female form with the head lying near the tropics, the feet at Tierra del Fuego, the spine and nervous system along the Cordillera; the breasts are the northern mountains, the belly is the flat pampa, and the womb is Buenos Aires - visibly a rockpile of mediocre architecture peopled by millions of lonely souls but, invisibly, "the fervent matrix, the sex of the nation". (The Malvinas, or Falklands, become a fallen slipper for the English to play with). The savior who is to reveal this submerged Argentina cannot be the hero of old. He transcends class, region, and profession. He is the preocupado, sensitive to surroundings, contemptuous of material life, disturbed by the spreading chaos of values, vibrantly concerned to affirm the individual and to lay bare the true nation beneath its fraudulence (15).

Mallea's short novel Party in November (1938) marshals his themes with evangelical clarity. At the outset he introduces Señora Ragué, a cruel and arid matron who officiates in a Buenos Aires mansion crammed with imported art and bric-a-brac. "Yes, I, Eugenia Ragué", she soliloquizes, "English by birth but Argentine by adoption, installed by my own will in this land I detest but whose strength $I$ have absorbed ...". And again: "We all carry within us two creatures, one of the city and another'. It was the other she hated, the provincial creature lurking like a poor relation in the dark corners of her mind". These lines recapitulate several classic motifs: the imperious English presence epitomized in Captain Head, the deprivation of Sarmiento's countryside, the bric-a-brac mansion of López' "great village".

Of the Señora's family only the daughter Marta matches her mother's strength, but her passion finds no point of engagement; immense ennui suspends her in a kaleidoscope of illusions. At her mother's party Marta meets Lintas, an artist attuned to the "submerged" Argentina. After he refuses to authenticate the Señora's newly acquired paintings, and thus to authenticate the occasion itself, Marta drives him to his apartment and is overcome there by a sense of life. Suddenly a scream pierces the night. Lintas explains that it is the cry of the demented widow of a bookseller who was murdered by hoodlums. Precisely that incident had shattered his own narcissistic shell, and the point is driven home that vitality lies not in the detritus of "civilization" but in the wakefulness which the arts help to kindle. Yet the tension between art and hypocrisy, between energy and sterility, has not eclipsed the historic one between town and nature. When the couple leave the apartment they pass the woods where the bookseller was killed.

(15) - - See John H. R. Polt, The Writings of Eduardo Mallea (Berkeley, 1959), p. 27. 
Restlessness charges the air, and Marta breathes the harsh aroma of leaves and bark, the heavy emanation of earth.

Throughout the novel the author intersperses a camera's-eye reportage of a poet who is seized by an armed patrol and executed. When he falls his blood flows across a courtyard, finds the morsel of bread he had been eating, and soaks it with the avidity of a living creature. The sacramental theme recurs in many of the works thus far examined: the suggestion of grace in Don Segundo Sombra, "the word" that establishes Martín Fierro's human condition, the hint of Fierro's martyrdom, the transfiguration of the aged plainsman in Facundo. Once given explicit focus, the religious motif offered escape from the issue of historical marginality with its cultural and social dilemmas. Leopoldo Marechal $(1898-$-) proved the case with his raucous, satiric, yet religiously illuminated novel Adán Buenosayres. Published in 1948 , it was rooted in the Buenos Aires of the 1920s, its characters inspired by the martinfierrista literary coterie (16) .

The prologue describes the author and five companions carrying the coffin of Adán Buenosayres to its grave. The novel then relates how Adán had experienced a "metaphysical awakening" in his room in Buenos Aires and devotes five "books" to the next two days of his life, leading him to the church of San Bernardo before the image of Christ of the Broken Hand, where angels and devils fight for his soul. Book VI, "The Notebook with Blue Covers", presents Adán's spiritual autobiography and bears intentional affinity to Dante's Vita Nuova. In the final book Adán makes a Dantean descent to the tormented city of $\mathrm{Ca}$ codelphia, infernal counterpart to "visible Buenos Aires" and presumably a spoof on Mallea's "invisible Argentina".

The novel torrentially documents a Ulysses-like pursuit of roots, spiritual ancestry, self, and salvation. During its course Adán envisions himself in a string of heroic roles from an Aristotelian ruler to Jack Dempsey in Madison Square Garden. The dramatis personae include classical literary figures, gaucho heroes, and a swarm of immigrants, intellectuals, playboys, foreign imperialists, and prostitutes. For all its frenzy, the quest has a genesis and an arena, as the searcher's names, "Adam" and "Buenos Aires", unequivocally convey. Although Marechal's novel yields Dantean and Joycean echoes, one would be condescending to pretend that it exhibits the craft and sustained power of a

(16). - In his "Autobiographical Essay" (in The Aleph and Other Stories 1933-1969, New York, 1971, p. 164) Jorge Luis Borges recalls that in 1924 he was taken into two literary sets in Buenos Aires, one grouped around Güiraldes, the other around the review Martin Fierro. He claims to have disliked the martinfierristas, French affectation that literature is reborn every morning like Adam and that it is the business of factious cliques. 
world classic. What gives it interest for our purposes is that the author finds his Florence or Dublin in Buenos Aires. The city, however makeshift its history and society, still affords a starting-point, is rich with persons, situations, and traditions that offer wherewithal for a personal destiny and view of the world (17). The first page pictures sonorous ships spilling the industrial harvest of two hemispheres on the docks of Buenos Aires, along with the color and sound of four races, the iodine of seven seas. Other tall ships laden with fauna, flora, and minerals embark in eight directions amid a harsh farewell of sirens. For the economist, export dependency perhaps. But for the novelist a center, not a periphery .

Marechal's Buenos Aires is present and encompassing. It is neither a city in incubation, like that of Sarmiento and Alberdi, nor a community recollected like that of Lucio $\mathrm{V}$. López. The spiritual pilgrim may be the author or Adán or the city or the nation, but at any point the boundary between the protagonist's mind and its surrounding universe is distinct. The creative act does not dissolve piquant externals of time and place, as in Martín Fierro and Don Segundo. Nor does it harness those externals to personal obsessions, as with Mallea. The private urgencies of Adán-Marechal imbue the setting with meanings, but on terms of transaction, not fusion. Other writers courted solipsism (Hernández and Güiraldes by dissolving society into a general state of soul, Mallea by translating it into his own state of soul); Jorge Luis Borges has even espoused it. Marechal may chronicle an overbearing, even narcissistic ego, but one which knocks up against the world.

Jorge Luis Borges (1899 -), Marechal's martinfierrista comrade of the 1920s who is affectionately caricatured in Adán Buenosayres, poses the quandaries of Adán-Marechal in ultimate terms. In so doing he relaxes the tensions created by one's search for identity as an Argentine or a porteño but heightens the larger mysteries of self, matter, knowledge, eternity, and death .

As a youth Borges went to Europe, spent World War I in Switzerland, then traveled to France and Spain consorting with the literary vanguard, and returned to Argentina in 1921. Even after such cosmopolitan exposure his first book, a volume of poems, bore the title Fervor of Buenos Aires (1923). Its localism and reflective tone betrayed the Ultraist tenets he had endorsed. He had not yet mastered the knack of yoking reasoned philosophy to perceived immediacies. Perhaps, he mused years later, this was because he had assumed that he had been raised in a Buenos Aires suburb of "uncertain streets and

\footnotetext{
(17). - Marechal offers his "keys" to the novel in Las claves de Adan Buenosayres (Mendoza, 1966).
} 
visible sunsets", while in truth he had grown up in a walled garden and a library of English books. For all the travel, reading, and friendships that ensued, he was inclined to think he had never left that library or garden. "What have I done since, what will I do, but weave and unweave imaginings derived from them?" (18).

A garden attentively contemplated leads more surely to the universal and ineffable than does a turbulent creole metropolis, which diverts one toward the regional and problematical. (Julio Cortázar formalizes the study of trivia in a Manual that offers painstaking instructions on how to weep, climb stairs, or kill ants in Rome). One of Borges' tales consummates the marriage of the banal to the mystic whole. An obtuse poetaster invites Borges to his basement to see the Aleph which will soon be lost in the demolition of his house. Borges descends in the dark and finds a sphere, an inch in diameter, of unbearable iridescence which contains all space and reflects all things from every angle. In this ordinary cellar in Buenos Aires he was gazing on "that secret and conjectured object whose name is common to a!l men but which no man has looked upon - the unimaginable universe". Elsewhere Borges asserts that the Argentine writer, no less than any other, has the universe for his patrimony. He should not "try" to be Argentine, for being Argentine is either an inevitability or an affectation.

The Europe which for so long had the mission to breathe energy into the lethargic Argentine hinterland, which for so long had made Argentine city-culture seem stilted and derivative - this Europe holds no fears for Borges. He calmly turns it on its head by exploiting precisely those European philosophers - Pascal, Leibnitz, Berkeley, Hume, Schopenhauer - who dissolve time, matter, and causation. Once the march of history is arrested and its meaning becomes mysterious, then all events may inhere in a single one and all careers in a single life. In "Kafka and his Precursors" Borges shows that history can work backwards. Because of Kafka, we now read a poem by Browning differently. If, then, a writer "creates" his precursors, why may not Buenos Aires modify the Paris of which it is said to be a passive and imperfect copy?

This question captivates Julio Cortázar (1914 -), whose apprenticeship in the world of fantasy finally maneuvered him to an "existential" vantage point. The perennial concern with cultural roots suffuses his major novel, Rayuela (Hopscotch, 1963), set in Paris and Buenos Aires and divided into three parts: "From the Other Side",

(18). - Ana María Barrenechea, Borges the Labyrinth Maker (New York, 1965), pp. 10-11. Also Borges' "Autobiographical Essay," p. 155: "I feel that all during my lifetime I have been rewriting that one book." 
"From this Side", and "From Diverse Sides". The schema suggests conventional handling of the ancient dichotomy. But the "table of instructions" advises that the book is many books, above all two: the first to be read normally, the second in a sequence that stitches hither and yon across all three sections and ends with an infinite ricochet between Chapters 131 and 58 (19). Thus whereas the necromancer Borges stages indecipherable riddles before our startled eyes, Cortázar enlists us in a participant quest to decode the mysteries, each for himself.

Cortázar acknowledges the "attempt to find a center" as a primary personal problem. Rayuela, named for a children's game that is played on a diagram with compartments for heaven and hell, "shows to what extent the attempt is doomed to failure", in that one cannot easily slough off the Judeo-Christian tradition one has inherited and been shaped by (20). Nonetheless, in such stories as "Axolotl", whose narrator turns into the salamander he has been scrutinizing in an aquarium, or "Night Face Up", in which a man under surgery in Buenos Aires dreams he is a sacrificial prisoner of the Aztecs when in fact he is a figment of the Indian's dream, Cortázar boldly reduces the ancient conundrum of identity to quintessential terms.

The interpretation being developed, at least provisionally, is not that Borges and Cortázar have produced a rarefied, exquisite, possibly decadent terminal statement of the historic creole dichotomy, but rather that, in a whole world whose center no longer coheres and where "identity" is universally evanescent, the experience of a hitherto "peripheral" people becomes, as it were, "central". Marginality and uncertainty are at the core, ancient certainties and shibboleths at the circumference. For Cortázar the Buenos Aires-Paris dyad is no more than heuristic.

Cortázar assaults ultimate mysteries with the resourcefulness of an urban guerrillero, a Tupamaro, doing his utmost to recruit the reader as a confederate. Yet once a particular chasm is to be bridged, the bemused reader can but gasp at Cortázar's private determination to effect linkage, as when in the dizzying incident in Rayuela Talita ventures across the teetering boards between two apartment windows to bring some nails and mate from one man to another in a desperate enterprise of communication. At other times the reader wonders if

(19). - A later story, "The Other Sky," manages more fluent traffic between the two cities. The narrator, living in Peronist A:gentina and engaged to the generous Irma, needs only to stroll in the city to find himself transported to the Paris of the Franco Prussian War and to his French mistress Josianne.

(20) . - See Cortázar's interview in Luis Harss and Barbara Dohmann, Into the Mainstream (New York, 1967), pp. 206-45. 
he is enlisted to decode or merely to celebrate, as when Cortázar casually regroups his tales of fifteen years under the categories: rites, games, passages. At still other times one senses that the author's mission is to compose a miniature divine comedy of classification. In this, Cortázar renews Marechal's scrutiny of single persons. His types are three: "famas" (archetypically, heads of philanthropic societies), "esperanzas" (who let things slide and never bother), and "cronopios" (whose world might begin rather than end with Picasso, a world where Louis Armstrong might play for hours from atop a streetlight, coaxing chunks of stars made of syrup and strawberries to tumble down for children and dogs) (21).

If we have strayed again from cities as such, it is because today's writer no longer perceives the city, or the nation for that matter, as a thing in itself, as an engine of salvation or corrosion. One theme of our trajectory is the vision of Buenos Aires as being, successively, on the fringe of the savage pampas, on the fringe of civilized Europe, at the center of its nation, and finally as providing a mere fragment of a proscenium for a drama perhaps universal, perhaps timeless, perhaps even meaningless, but certainly enigmatic. The old dichotomies may persist but are now reversible, or at least syncopated.

And now we confront the fact that if ancient verities are under question, among them is the cumulative action of time. Borges and Cortázar, who so neatly seem to close our trajectory, warn us that perhaps no trajectory is possible, that time may be impotent. If, for example, we think of our writers not in generational sequence but as figures in a Borgean labyrinth, we can easily see them as pursuing each a private path. The design of the labyrinth may be inscrutable. Or, if it were Borges' "garden of the forking paths", the destinies might separately culminate in a common denouement. Still again, each path might bend back on its starting point. Time would therefore not have "worked". And suddenly we see Borges, not as the consummate artist who lifts the curse of parochialism from Argentine letters, who renders Buenos Aires no less hospitable to the free spirit than Paris or London, but as a latter-day Captain Head (22). After all Fanny Haslam,

(21). - Rita Guibert, Seven Voices (New York, 1973), p. 280.

(22). - The aristocratic aloofness of Borges, his ludic speculations on the efficacy of time, his casual dismissal of nationalist urgencies make him a perennial target for the political left and for "engaged" literati. He seems to have survived the "pariicidal" attack of the 1940s (see Emir Rodriguez Monegal, El juicio de los parricidas, Buenos Aires, 1956, pp. 55-79) and perhaps will not be laid low by a recent exegesis that attributes his sovereign disengagement from the "real" world to assorted sexual and parental fixations (Blas Matamoro, Jorge Luis Borges o el juego trascendente, Buenos Aires, 1971). Matamoro tosses a brick for good measure at Cortázar for being an elitist, cosmopolitan liberal. 
his grandmother, was a devotee of Arnold Bennett, Galsworthy, and Wells; his father pondered Berkeley, Hume, and William James, idolized Keats and Swinburne, inspired his son's love for paradox and conundrum. When Borges recruits English writers to "liberate" the Argentine soul, is it that the method is ironic? Or that the liberation is illusory? How do we interpret his passion for Old English and his asser* on that he finds learning Anglo-Saxon as intimate an experience as inoking at a sunset? Can it be that Borges's childhood garden in Buenos nires was not the labyrinth of the universe but one of those manicured British yards which Sarmiento seized on as an object lesson for the indolent creole? Or is Borges, perchance, the last of those dissolute, expatriate Cornish miners on whom Sir Francis Head lavished such pity? If either of the last two questions deserves a qualified yes, "allogenetic" might indeed be the word for Buenos Aires. And our trajectory would stand on its Head. 